\title{
EXTINCTIONS AND APPEARANCES OF THE MID-CRETACEOUS PLANKTONIC FORAMINIFERA- FORCED, VOLUNTARY OR A MERE COINCIDENCE?
}

\section{TEWARI, Archana and HART, Malcolm B.}

Department of Geological Sciences, University of Plymouth, Drake Circus, Plymouth PL4 8AA, United Kingdom.

The Cauvery Basin, SE India, is one of the best exposed late Mesozoic to Tertiary basins in India. Micropaleontological studies in the Basin started in 1950's, but did not extend beyond taxonomic descriptions. It is only relatively recently that the applied aspect of micropaleontology, foraminifera in particular, has been acknowledged in India. The full academic and economic use of foraminifera remains, yet, to be fully appreciated.

The study of mid-Cretaceous foraminiferal assemblages from the shelf sediments of the Cauvery Basin (SE India), shows two prominent levels of important foraminiferal changes. Major morphological changes within the planktonic fauna occur in the late Albian and in the late Cenomanian-early Turonian intervals. In the late Albian juveniles of Rotalipora Brotzen, Planomalina (Gandolfi) and Praeglobotruncana Bermudez appeared. Full expansion of the fauna was characterised by Hedbergella Bronnimann \& Brown, keeled forms belonging to Rotalipora species and Pl. buxtorfi (Gandolfi) and high spired and highly calcified $\underline{P}$. stephani (Gandolfi) and $\underline{P}$. gibba Klaus.

The late Cenomanian-early Turonian saw major readjustment in the planktonic fauna. The keeled Rotalipora and Planomalina became extinct and Hedbergella were greatly reduced in numbers. The Albian assemblage was replaced by new genera and species. In the late Cenomanian-early Turonian Dicarinella Porthault, Whiteinella Pessagno,

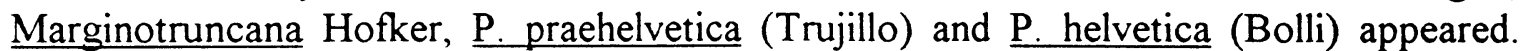
From a stock of small, weakly ornamented forms developed robust, highly ornamented, high spired and plano-convex forms, that expanded in the Turonian. The development of high-spired $\underline{P}$. stephani, $\underline{P}$. gibba, $\underline{D}$. hagni (Scheibnerova) and $\underline{M}$. schneegansi (Sigal) and strongly plano-convex $\underline{P}$. praehelvetica, $\underline{P}$. helvetica and $\underline{D}$. hagni was very significant.

These levels of important foraminiferal changes occur within the mid-Cretaceous oceanic anoxic events, resulting from the eustatic sea-level rises. These sea-level controlled anoxic events disturbed the ocean system e.g.- nutrient influx, $\mathrm{pH}$ values, expansion of oxygen minimum zone, etc.. So, was the planktonic community responding to these changed conditions during the anoxia? In that case the changes were forced on the then inhabiting community. An alternative is, that these were voluntary evolutionary changes. A completely different approach is, that this was a mere coincidence. These pros and cons are addressed in the study. 